\title{
Deck Engineer on Barge Dies When Struck by Crane Counterweight in Washington State

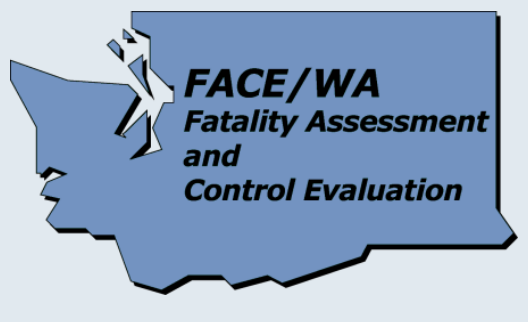

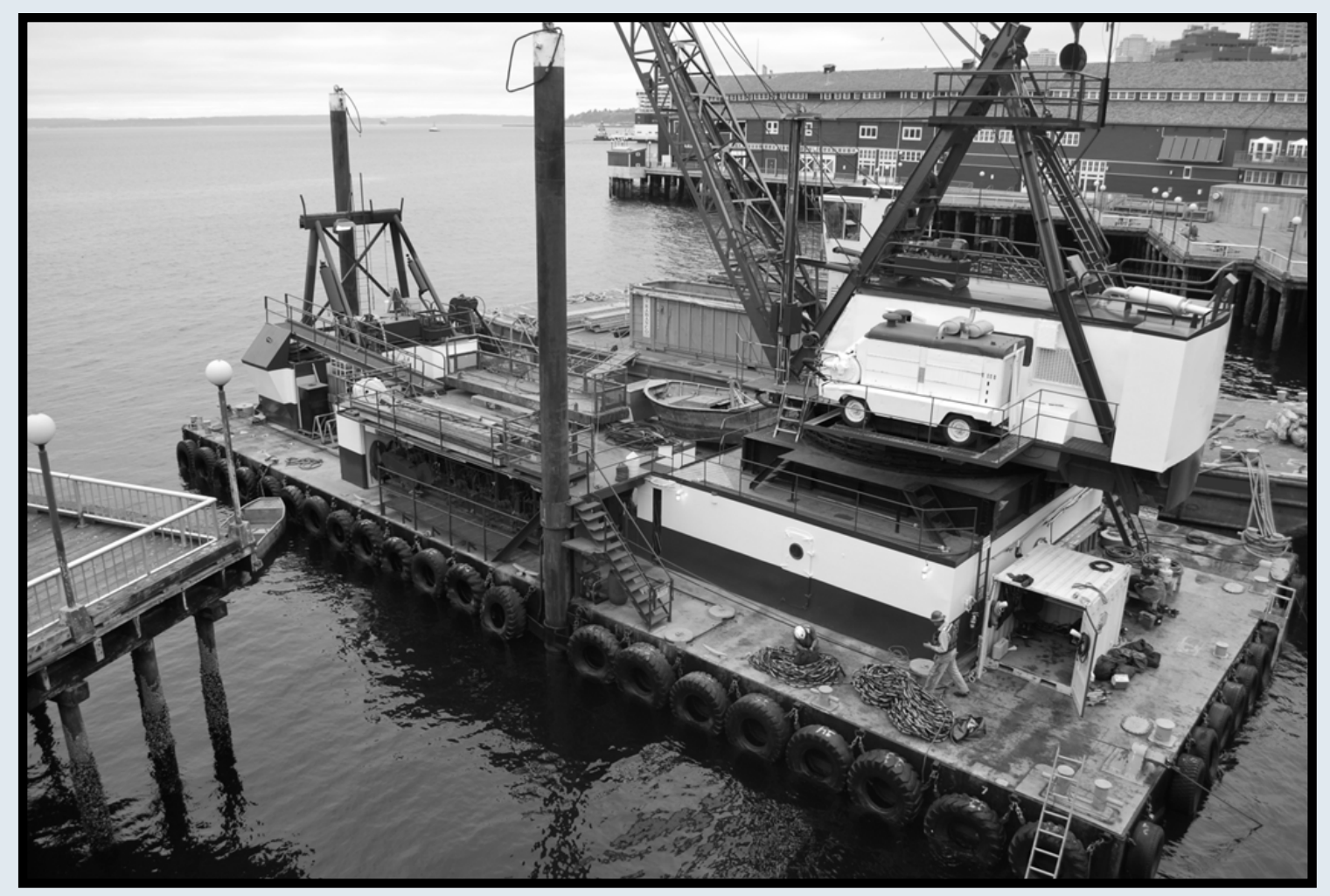

Investigation: \# 10WA040

Release Date: June 8, 2012

SHARP Report: \# 52-24-2012 
SUMMARY

RECOMMENDATIONS

INTRODUCTION

Employer

Employer Safety Program and Training

Victim

Equipment

6

INVESTIGATION

CONTRIBUTING FACTORS

CAUSE OF DEATH

RECOMMENDATIONS AND DISCUSSION

REFERENCES

APPENDIX

INVESTIGATOR INFORMATION 20

FACE PROGRAM INFORMATION 21 


\section{SUMMARY}

In June of 2010, a 26-year-old female deck engineer died when she was struck by the counterweight of a barge mounted crane/derrick. The deck engineer (victim) and a crane operator, both employees of a marine construction company, were working from a crane/derrick barge in support of a crew working at a job site on a project to replace pilings underneath a pier. The project involved having divers in the water and workers in small boats taking out the old pilings and replacing them with new ones. The crane operator on the crane/derrick barge would operate the crane to lift waste pilings from the water and place them on an adjacent barge and lift new pilings and other supplies to workers in the water.

The victim was an apprentice heavy duty repair mechanic and an inexperienced deck engineer who had worked in the company shop for the past 10 months; this was her third day on the job as a deck engineer. She was welding repairs to a guard railing on the barge's upper deck when the crane operator rotated the crane to make a pick of pilings from the water. The crane's counterweight struck her in the head and neck, pinning her against the railing.

A bystander on the pier alerted company employees that she was hurt. An employee went to check on the victim and found her unresponsive. Another employee called emergency medical services (EMS). As an employee was applying an Automated External Defibrillator (AED) to the victim, EMS personnel arrived and began CPR. She was then removed from the barge and taken to a hospital where she was declared dead. 
To prevent similar occurrences in the future, the Washington State Fatality Assessment and Control Evaluation (FACE) investigation team recommends that employers who use cranes should follow these guidelines:

- Ensure that the area within the swing radius of the rotating superstructure of a crane is barricaded so as to prevent workers from entering and being struck.

- Ensure that a method of communication is established and that communication is maintained between the crane operator and other workers and that the crane and its superstructure do not move until the "all clear" signal is given.

- Lock out/tag out the crane when workers need to perform work that will expose them to the hazard of being struck by the crane or its load.

- Train employees performing work in a crane's vicinity or in support of the crane operator to recognize and avoid the hazard of being struck by the rotating crane superstructure and its counterweight.

- Hold a daily pre-work safety meeting to break down each task and identify the potential hazards so that the site supervisor, crane operator, and work crew are all aware of the hazards and safe working practices when performing their tasks.

- Consider having an experienced employee work alongside a new or inexperienced employee so as to provide on the job training on how to work safely in a potentially hazardous environment.

- Consider installing electronic proximity sensing devices to warn the crane operator of workers on foot in the vicinity. 


\section{INTRODUCTION}

In June of 2010, the Washington State FACE Program was notified by the Division of Occupational Safety and Health (DOSH) of the death of a 26-year-old female deck engineer who died when she was struck by the counterweight of a barge mounted crane. In September of 2011, Washington State FACE investigators traveled to the company's office and interviewed the company's northwest regional safety manager and visited the incident site with the safety manager, where they viewed the incident crane barge. Photographs were taken of the incident crane barge, which was approximately at the same location as it was at the time of the incident. During the course of the investigation documents reviewed included the victim's death certificate, and OSHA incident investigation file, photographs and report.

\section{Employer}

The employer is a marine construction and dredging company that has been in business for many years and is headquartered in Washington State. Its marine construction projects have included marinas, piers, terminals, wharves, and bridges, among others. The employer maintains a fleet of over twenty derrick barges and dredges. Approximately 650 - 700 employees belonging to several trade unions work out of five offices in the U.S. The regional office where the victim worked has about 150 -200 employees. The employer yard has over 60 employees.

Two employees were at the incident site working from the crane barge, a deck engineer (the victim) and a crane operator. The second barge used for staging construction materials had two employees. In addition, there were several employees working from small boats or skiffs. The employer started work on the project at the incident site approximately two months previously.

\section{Employer Safety Program and Training}

The employer did have a safety and health program which included a section on crane safety that addressed physically guarding the swing radius of the crane. The employer provides safety orientation training for new employees. This includes training in awareness of hazards present in the employer yard and training in safe operation of specific equipment, such as forklifts.

The employer has a regional safety manager who is responsible for ensuring the safety of employees and providing safety trainings and toolbox talks. The regional safety manager reports to the company director of safety and the area vice president. At the time of the incident, employee safety meetings for supervisors were held once a week, now they are held daily at 7AM before the start of work. After the meeting the supervisors then complete a written job safety analysis (JSA) which includes a review of 
work to be performed that day and the tasks involved, with the hazards noted and steps that should be taken to work safely. The JSA is then gone over with employees for whom the supervisor is responsible. Safety training appropriate to the individual's trade is also provided by the various unions. There is no labor/management safety committee. The safety manager was not present at the incident site.

Post-incident the employer is in the process of creating an integrated companywide safety management system.

\section{Victim}

The victim was a 26-year-old female who worked full-time for about 10 months as a mechanic/welder doing maintenance and mechanical repair work in the employer's shipyard. She was learning the various skills that she would need to be a deck engineer. She was a member of the International Union of Operating Engineers (IUOE) and was a few days away from completing her apprenticeship as a heavy duty repair mechanic. Her training also included completion of the Washington Association of Building Officials (WABO) welding certification program, Contractor Safety Training and Orientation Program certificate, 40 hour HAZWOPER training, OSHA 10 hour construction safety training, and equipment mechanic training at a technical college. Her job history included $2 \frac{1}{2}$ years with a construction company as an equipment mechanic apprentice and deck engineer and 2 years as a shop help welder.

She had previously worked as an apprentice deck engineer on a barge for an unknown period of time for another employer. The employer liked her work and decided to promote her to the position of deck engineer. The day of the incident was her third day working as a deck engineer on the incident barge.

\section{Equipment}

The crane involved in the incident was a mast type crane or derrick that was mounted on a 107-foot long by 52-foot wide barge (see photos 1 and 2). The crane has a maximum lifting capacity of 50 tons. The crane barge has a lower deck with areas used for maintenance work and storage and a crew quarters. On top of the crew quarters there is an upper deck with an elevated metal platform. The crane's turntable is mounted on top of the elevated metal platform. The turntable supports the rotating superstructure of the crane.

A metal guardrail consisting of a toprail and midrail is mounted on three sides of the upper deck (on one side of the upper deck the crane platform extends to the edge of the deck). The crane cab can be accessed from the upper deck via metal stairs on the barge's port and starboard and stern; there is a metal ladder on the stern. 
The crane operator had been with the company for over 30 years and was a National Commission for the Certification of Crane Operators (NCCCO) certified crane operator. The incident crane was, as required by OSHA regulation, certified as having met requirements for safe operation in construction work.

\section{INVESTIGATION}

In June of 2010, a deck engineer (victim) and a crane operator were working from a crane barge. They were part of crew working at job site on a project to install falsework ${ }^{1}$, remove creosoted wooden pilings and replace them with galvanized pilings underneath a historic pier on the waterfront of a large city in western Washington State. The pier has a number of shops and restaurants and is adjacent to a city park with waterfront viewing areas. The project involved having divers in the water and workers in small boats taking out pilings and replacing them with new ones.

There were two barges being used to support the work anchored near the pier. One barge had a crane which was used to move materials and equipment in and out of the water for employees and a subcontractor's divers working under the pier. The second barge was used to hold the new replacement pilings for the pier, the old pilings that were removed, and other construction materials and supplies. This second barge was where the crane operator would lift and deposit waste materials from the water and pick replacement pilings for crews working from the water. The project had been ongoing for about two months.

On the incident day, the victim began her third day as a deck engineer on the barge by preparing the rig and the crane before the crew showed up. This involved fueling, checking the oil, servicing of the engine, and starting-up the crane. The weather was approximately 63 degrees Fahrenheit, with a seven mile per hour wind, with no recent precipitation, and mostly cloudy.

A safety meeting was held at the job site with the victim, crane operator, and other workers assigned to the support barge and skiffs. The day's work tasks were planned and safety issues related to these tasks were discussed. Staying out of the crane's swing radius was mentioned as part of the verbal JSA at the meeting. There was no written record of the meeting nor was a JSA form filled out. Normal company procedure would have a site supervisor and engineer at the site to ensure that a JSA form is filled out; neither were at the safety meeting.

1. Temporary construction work on which a main work is wholly or partly built and supported until the main work is strong enough to support itself. (Source: Merriam-Webster Dictionary) 
The victim, who reported directly to the crane operator, spoke with the operator about tasks for the day. One of the tasks they agreed on included a welding repair to a portion of a guardrail consisting of a toprail and midrail on the upper deck of the barge. The repair was not considered high priority, but could be done when the victim had time to do it and operations allowed.

The further duties of the victim included putting skiffs in the water, maintaining a clean galley, assisting the hoist crew which included workers in skiffs and a dive team, servicing deck machinery, general clean-up, painting, and making repairs to machinery and the barge. This crane barge was in very good condition and was recently painted. The crane operator and victim were the only workers on the barge. During the course of the project the pace of work on the barge had been slow with an average of $6-8$ picks per day by the crane. A pick would take perhaps five minutes at most. That morning prior to the incident there had been approximately two picks. There was a lot of down time for the crane operator and support crew.

The area on the upper deck in which the victim was intending to weld was within the swing radius of the crane counterweight. At the bottom of the port side stairway between the barge's lower and upper deck ordinarily there was a safety chain with a sign that read "CAUTION: STAND CLEAR OF SWING RADIUS." This safety chain with the warning sign attached was meant to act as a barricade to be put up whenever the crane is operating. This was intended to keep workers from accessing the upper deck where they could be exposed to the area of the swing radius of the crane and the struck by hazard of the crane counterweight. On the day of the incident this safety chain was not in place. It is unknown how long the safety chain had been down; it may have been taken down while painting was being done prior to when the victim began her work as a deck engineer on the barge.

The victim, known as a conscientious, safe worker, applied herself to the task of repairing the rail. It is unknown what time she began this task or exactly what she was doing prior to this. She was welding the rail while wearing a welder's hood with a full face shield, gloves, and a hard hat. She was not wearing hearing protection.

Standard company procedure requires the crane operator to establish contact by radio with the deck engineer before operating the crane. All employees on the project had radios and the crane operator controlled radio communication. The victim had a radio in a pocket of her personal floatation device which was placed beside her on the deck. The radio was turned on and could reportedly be heard despite the noise from the welding and the environment.

At approximately 10:45 to 10:50 AM the crane operator received a radio communication from a worker in a skiff that old pilings in the water needed to be picked up and 
deposited in the garbage dumpster on the second barge. The crane and its boom were facing the shore. The crane operator seated in the crane's cab could not see the victim who was working in his blind spot to the rear right side of the crane as it was positioned.

Prior to moving the crane, the crane operator did not establish radio contact with the victim; it was reported that he believed her to be working outside the radius of the crane counterweight swing. She was, in fact, working just inside the rail on the upper deck. The crane operator then picked up the waste piles out of the water and rotated the crane left or counterclockwise. As he did so, the crane's counterweight struck the victim in the head and neck, pinning her against the rail.

A bystander on the pier alerted two company employees in a skiff that that a coworker on the barge was injured. An employee radioed the crane operator who shut down the crane and another employee on the second barge was contacted who then went to check on the victim. An employee called 911. An employee found the victim unresponsive and started to apply an Automated External Defibrillator (AED). As the employee was applying the AED, emergency medical technicians arrived and began CPR. The victim was moved from the barge to the pier and transported to a hospital where she was declared dead on arrival.

\section{CONTRIBUTING FACTORS}

Occupational injuries and fatalities are often the result of one or more contributing factors or key events in a larger sequence of events that ultimately result in the injury or fatality. Washington FACE investigators identified the following items as possible factors that may contribute to worker injury from being struck by a crane's counterweight:

- Lack of barriers.

- No warning signage.

- Poor communication between crane operator and workers on-foot before crane movement.

- Insufficient training of employee in hazard recognition.

\section{CAUSE OF DEATH}

The medical examiner listed the cause of death as cervical spine fractures with pontomedullary transection, subdural and subarachnoid hemorrhage due to blunt force injury of the head and neck. 
Recommendation \#1: Ensure that the area within the swing radius of the rotating superstructure of a crane is barricaded so as to prevent workers from entering and being struck.

Discussion: Areas that workers are able to access within the swing radius of a crane's superstructure present a hazard of being struck by, crushed, or pinched between the rotating superstructure and a stationary object (1). Employers should restrict those areas within the crane's swing radius from entry so as to prevent injury to workers $(1,3$, $6,7,8)$. Methods of marking the boundaries of the swing radius hazard area include control lines, warning lines, railings, and other similar barriers. In this incident the area within the swing radius of the crane counterweight was not barricaded. The safety chain with a warning sign serving as a barricade was not in place at the bottom of the stairs which allowed access to the barge's upper deck and crane swing radius area. Though the crane was making picks infrequently, the area within the crane swing radius should have been barricaded to prevent access, as it presented a hazard of being struck by the crane counterweight.

For hazard areas where it is not feasible to erect barriers, post warning signs and create high visibility markings on equipment. Post-incident the employer installed metal swinging, self-closing gates on stairways accessing areas within the crane's swing radius on their barges. Attached to these gates are signs that read "DANGER - SWING RADIUS: No Entry Without Crane Operator Approval." In addition, the area on the upper deck within the swing zone of the crane counterweight is now painted with black and yellow stripes to indicate a hazard zone.

Recommendation \#2: Ensure that a method of communication is established and that communication is maintained between the crane operator and other workers and that the crane and its superstructure do not move until the "all clear" signal is given.

Discussion: Crane operators seated in the crane's cab often have blind spots, making it difficult for them to see the location of other workers. Therefore to prevent injury to other workers in the vicinity of the crane, it is essential that a method of communication be established and adhered to by the crane operator and other personnel $(2,3,4)$. The company in this incident had a policy requiring the crane operator to establish radio contact with the deck engineer before moving the crane. The crane operator had a radio with which he could establish contact with employees. Those who had hand held radios 
included the deck engineer and employees working from skiffs and on the storage barge.

The victim did not communicate to the crane operator her intention to proceed to the task of repairing the guardrail, which was in the swing radius hazard zone. The incident crane operator believed the victim was working somewhere else on the barge away from the crane swing radius and, accordingly, did not radio the victim to inform her of the lift and get her "all clear" confirmation before moving the crane. There was a communication breakdown in this incident. To prevent a similar occurrence, crane operators should establish contact with all other site workers and receive a positive "all clear" from them before rotating the crane's superstructure.

Recommendation \#3: Lock out/tag out the crane when workers need to perform work that will expose them to the hazard of being struck by the crane or its load.

Discussion: If a crane support worker deems it necessary to enter the swing radius area during operations, for example to perform repairs or maintenance, then they should communicate this to the operator. The operator will then physically lock out and tag out the crane, thereby preventing it from moving. When the worker has completed the task, communication should be made to the operator that the area is clear of all personnel and that operations can proceed.

Recommendation \#4: Train employees performing work in a crane's vicinity or in support of the crane operator to recognize and avoid the hazard of being struck by the rotating crane superstructure and its counterweight.

Discussion: Employers should train their employees working on or near cranes to recognize the danger of being struck by, pinched, or crushed by a crane's rotating superstructure. The safety training should address the specific physical characteristics of each crane around which employees are expected to work. The victim in this incident was verbally informed of the hazard of being struck by the crane, but was not given formal training Perhaps if the victim was fully trained in the hazards and the standard operating procedures of working within the crane's counterweight swing zone this incident might have been prevented.

Recommendation \# 5: Hold a daily pre-work safety meeting to break down each task and identify the potential hazards so that the site supervisor, crane operator, 
and work crew are all aware of the hazards and safe working practices when performing their tasks.

Discussion: Employers should ensure that daily pre-job safety meetings are held at each job site. The meeting topics covered should be specific to that site, the day's tasks, and hazards expected to be encountered. Also, each day, a written JSA should be developed and used to document each task, identify the associated safety hazards, and document the control measures taken to eliminate those hazards. A JSA was not developed or used on the day of the incident.

Recommendation \# 6: Consider having an experienced employee work alongside a new or inexperienced employee so as to provide on the job training on how to work safely in a potentially hazardous environment.

Discussion: When "breaking-in" a new employee or assigning an employee to a new and unfamiliar job where safety hazards are present, employers should consider having an experienced employee work alongside them for a period of time to familiarize them with their job duties and how to work safely.

Research has shown that newly hired workers and workers assigned to unfamiliar job tasks are more vulnerable to injury in their first month on the job (9). The victim had limited previous experience as a deck engineer. The day of the incident was her third day on the job in her new position on the barge. She previously worked in the company's repair shop at their yard and briefly for another employer as a deck engineer. She was not considered by her employer to be an experienced deck engineer. Her employer assigned her to this particular barge and this project because the pace of work was slow and they considered this job assignment to be a good learning environment for a new deck engineer. The employer's intention was to allow her to get accustomed to her job duties on a less busy and demanding project. The previous deck engineer on this barge was assigned to a different job site making the victim the sole deck engineer aboard the barge.

Recommendation \# 7: Consider installing electronic proximity sensing devices to warn the crane operator of workers on foot in the vicinity.

Discussion: In this incident the crane operator could not see the victim from the operator's cab. Research indicates that visibility issues are a significant factor in fatalities involving operators of construction equipment and workers on foot $(10,11)$. Electronic proximity sensing devices may provide further safeguards in protecting 
workers who are in the crane operator's blind spots from being struck by parts of a moving crane. Workers on foot who enter the crane swing hazard area without the crane operator's knowledge and are out of the operator's line of vision can be detected by various electronic devices that alert the operator of their presence. These devices must not supplant other safety controls such as barricades used to exclude workers from the hazard zone of the rotating crane superstructure and communication between workers on foot and the crane operator. These devices should be considered as a redundancy or a failsafe device in the worker safety system should other safety measures fail.

Proximity sensing devices and proximity detection systems have been used in the mining and construction industries where they have been mounted on mobile equipment and dump trucks to warn operators of the presence of workers on foot when they are in their blind areas $(11,12,13)$. Manufacturers have developed a number of systems using a variety of technologies. Some of these technologies include the use of a global positioning system (GPS), and distance sensors using ultrasonic, electromagnetic, radio frequency, radar, and laser based technologies $(12,13)$. For example, one promising technology is electromagnetic proximity detection which uses magnetic fields to sense workers in the vicinity of equipment. One way this may be applied is to have workers wear a device that is measured by sensors on the equipment which then issues a warning to the equipment operator or directly disables the equipment to prevent it from moving (13). 


\section{REFERENCES}

1. MacCollum, David V. (1993). Crane Hazards and Their Prevention. American Society of Safety Engineers, Des Plaines, Illinois.

2. Massachusetts Fatality Assessment and Control Evaluation Program (2005). Vibratory Hammer Operator Killed when Crushed Between a Crane Superstructure and its Left Rear Track. Massachusetts Fatality Assessment and Control Evaluation Report: 03-MA006-1. http://www.cdc.gov/niosh/face/stateface/ma/03ma006.html

3. California Fatality Assessment and Control Evaluation Program (1997). Crane Oiler Dies When Crushed Between a Crawler Crane Cab and Track in California. California Fatality Assessment and Control Evaluation Report: 97CA001. http://www.cdc.gov/niosh/face/stateface/ca/97ca001.html

4. California Fatality Assessment and Control Evaluation Program (2004). A Crane Oiler Dies When Crushed Between the Counterweights and the Rotating Superstructure of a Mobile Crane. California Fatality Assessment and Control Evaluation Report: 04CA003. http://www.cdc.gov/niosh/face/stateface/ca/04ca003.html

5. Haslam, R.A., Hide, S.A., Gibb, A.G.F., Gyi, D.E., Pavitt, T., Atkinson, S., Duff, A.R. (2005). Contributing factors in construction accidents. Applied Ergonomics, 36:401-415.

6. Code of Federal Regulations (2010). 29 CFR 1926.1424. Subpart CC. Cranes \& Derricks in Construction - Work Area Control. Washington, DC: U.S. Government Printing Office, Office of the Federal Register. http://www.osha.gov/pls/oshaweb/owadisp.show document?p table=STANDARDS\&p i $\mathrm{d}=73$

7. Code of Federal Regulations (2010). 29 CFR 1926.1437. Subpart CC. Cranes \& Derricks in Construction - Floating Cranes/Derricks and Land Cranes/Derricks on Barges. Washington, DC: U.S. Government Printing Office, Office of the Federal Register. http://www.osha.gov/pls/oshaweb/owadisp.show document?p table=STANDARDS\&p i $\mathrm{d}=115$

8. Washington Administrative Code. Safety Standards for Construction Work, Part L. Cranes, Derricks, Hoists, Elevators, and Conveyors. Chapter WAC 296-155. http://www.Ini.wa.gov/wisha/rules/construction/HTML/296-155L 1.htm

9. Breslin, F.C., Smith, P. (2006). Trial by fire: A multivariate examination of the relation between job tenure and work injuries. Occupational and Environmental Medicine, 63:2732. http://oem.bmj.com/content/63/1/27.abstract?sid=705872c9-632e-4e34-a930Ob8bfab62604

10. Hinze, J.W., Teizer, J. (2011). Visibility-related fatalities related to construction equipment. Safety Science, 49:709-718. http://www.sciencedirect.com/science/article/pii/S0925753511000099

11. National Institute for Occupational Safety and Health (NIOSH). Highway Work Zone Safety, Construction Equipment Visibility. http://www.cdc.gov/niosh/topics/highwayworkzones/BAD/default.html

12. National Institute for Occupational Safety and Health (NIOSH). Proximity Detection. http://www.cdc.gov/niosh/mining/topics/topicpage58.htm

13. National Institute for Occupational Safety and Health (NIOSH). Machine Safety Highlights, Intelligent Proximity Detection. http://www.cdc.gov/niosh/mining/highlights/programareahighlights6.htm 


\section{APPENDIX}

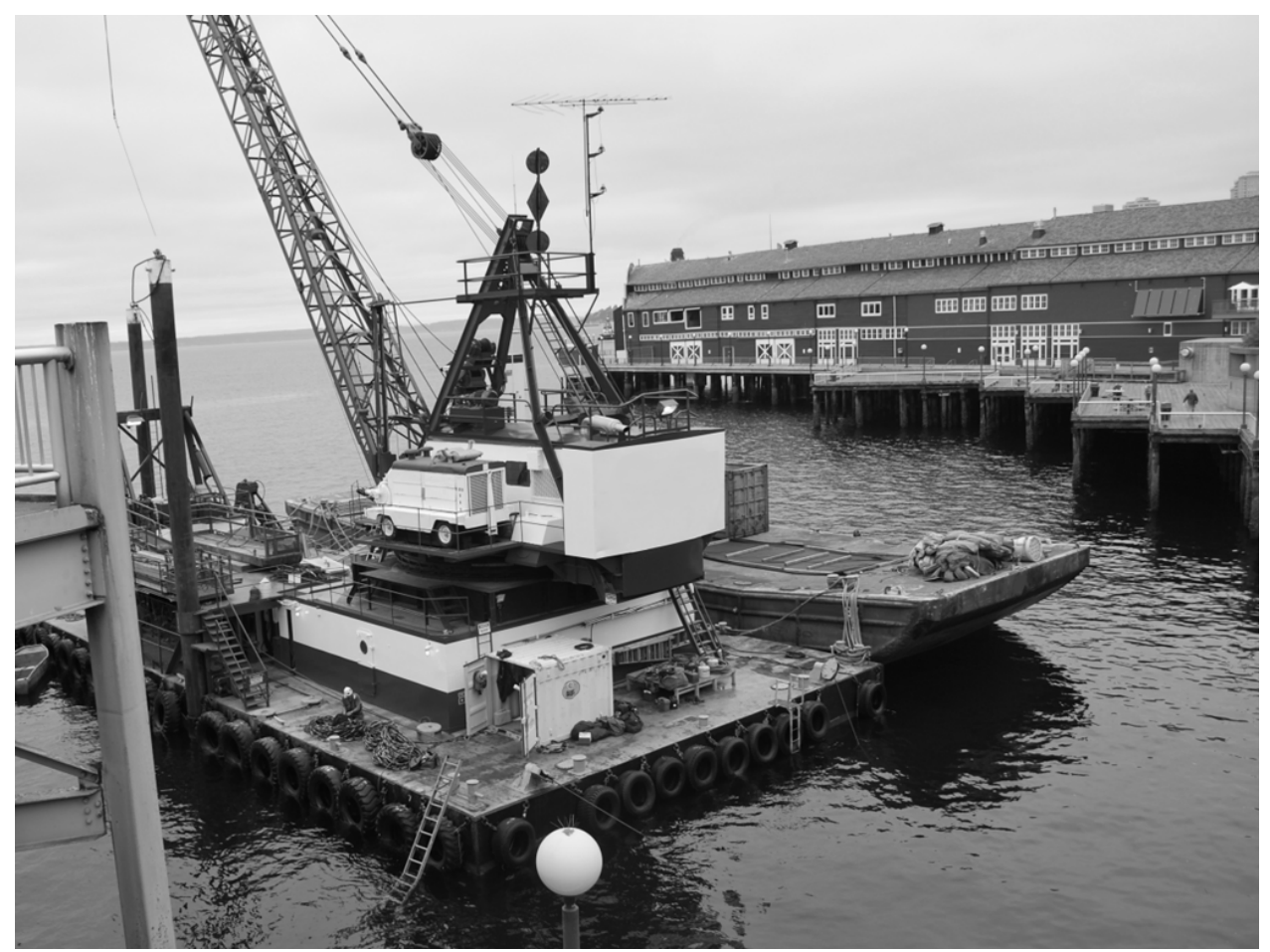

Photo 1: Crane barge at incident site (photo taken over a year later).

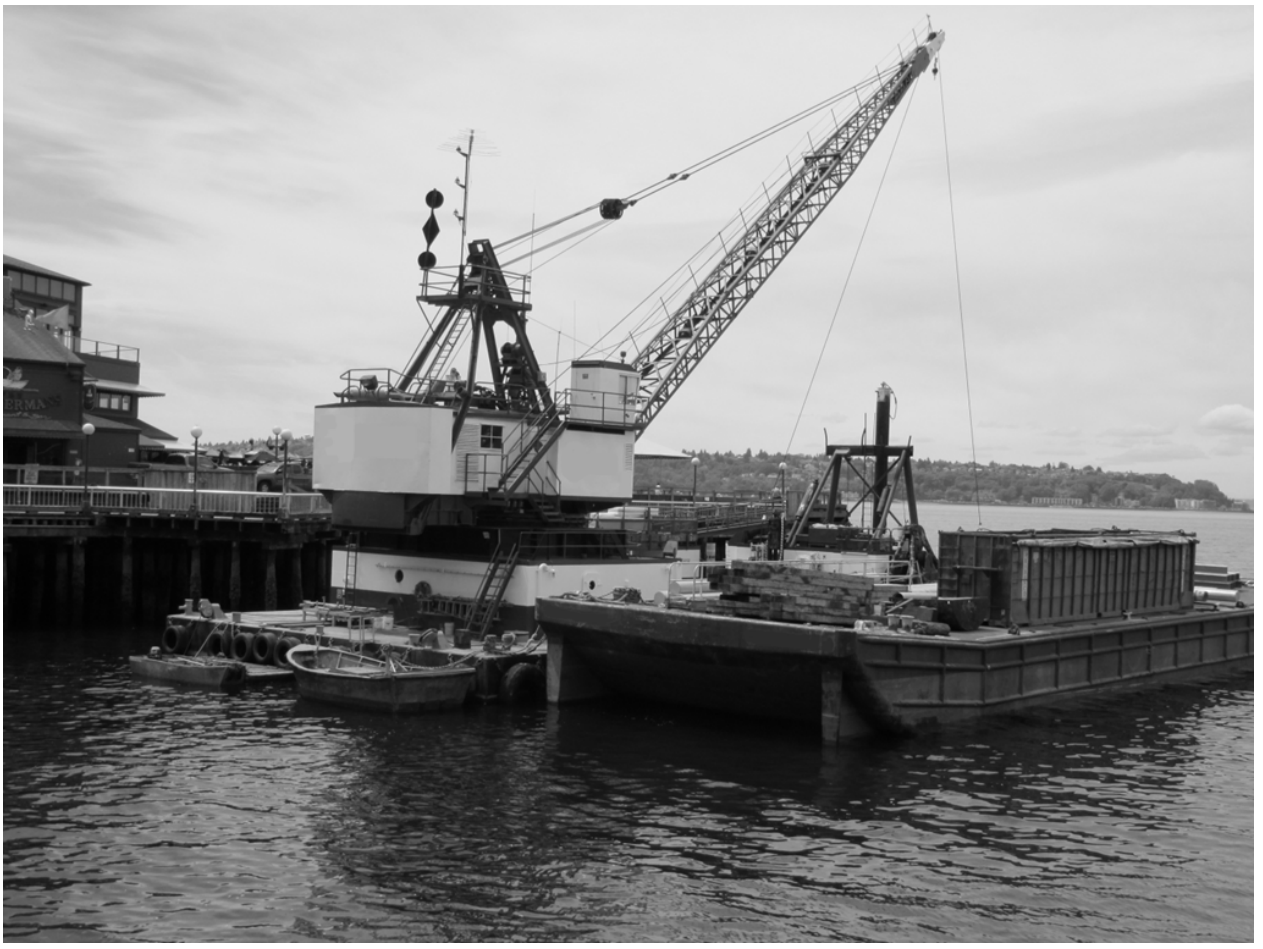

Photo 2: Crane barge and barge used for construction supply storage and waste materials at incident site (photo taken shortly after incident). 


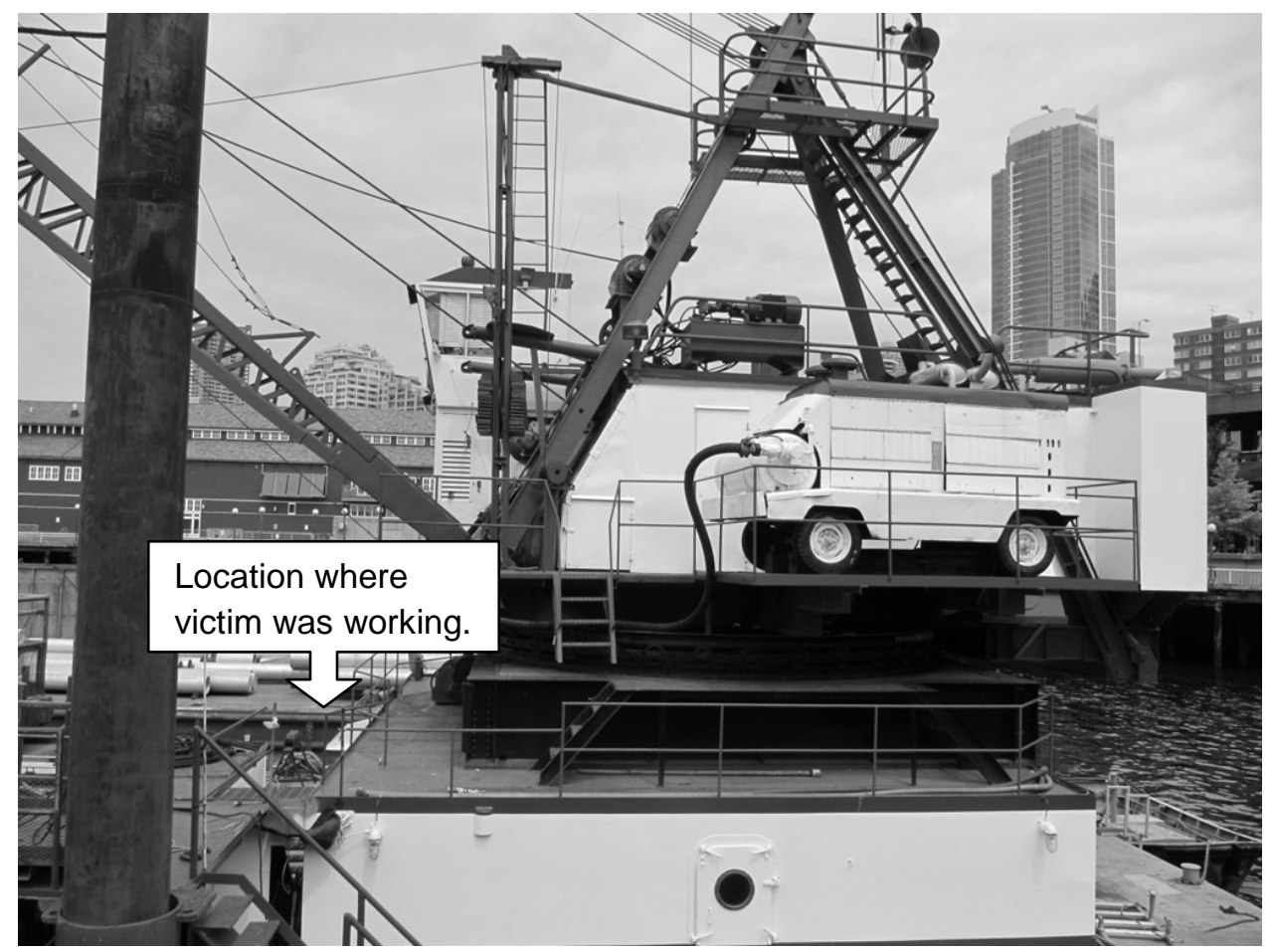

Photo 3: Crane and upper deck of barge where the deck engineer (victim) was welding a railing (photo taken shortly after incident).

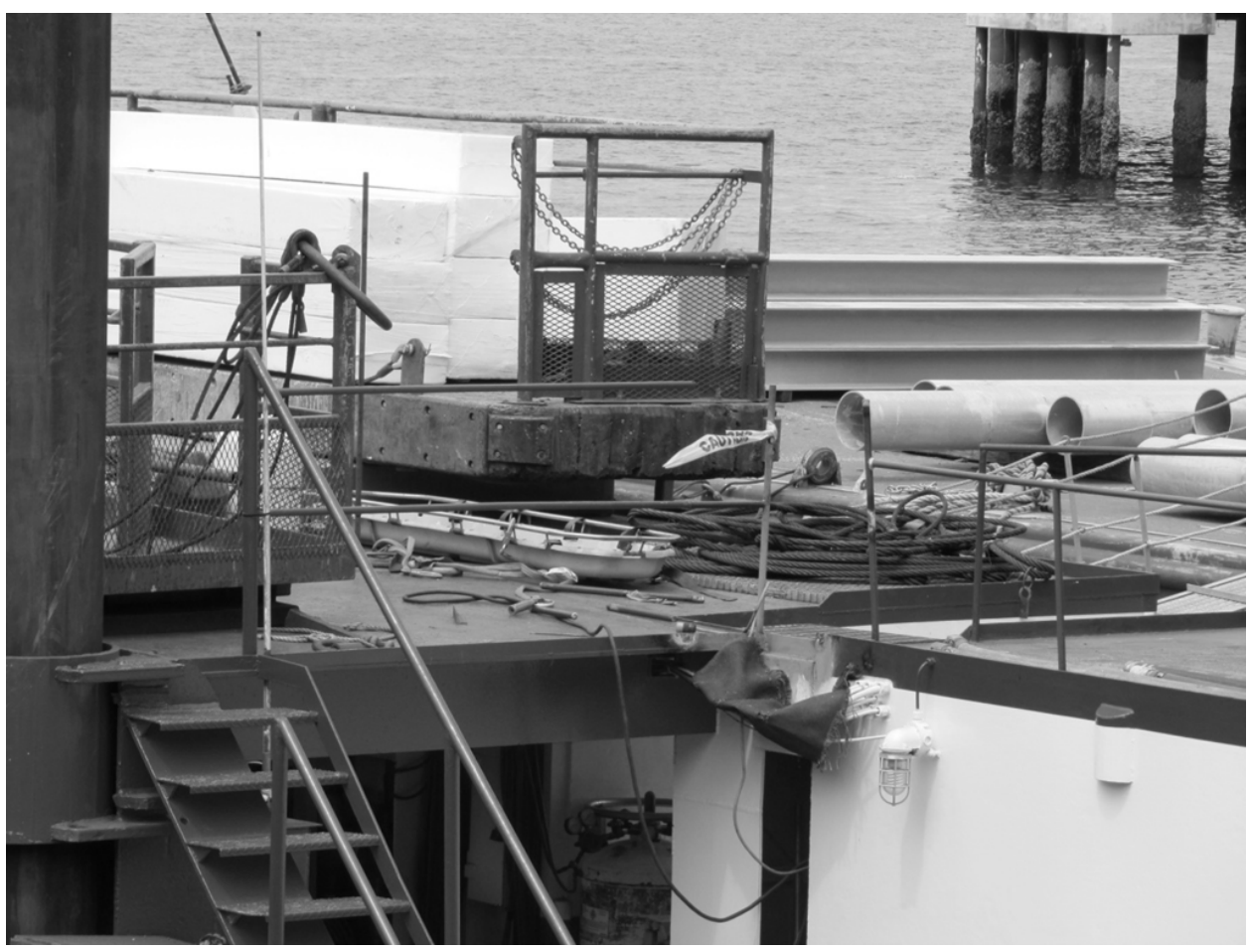

Photo 4: Upper deck of barge where victim was welding a broken railing (photo taken shortly after incident). 


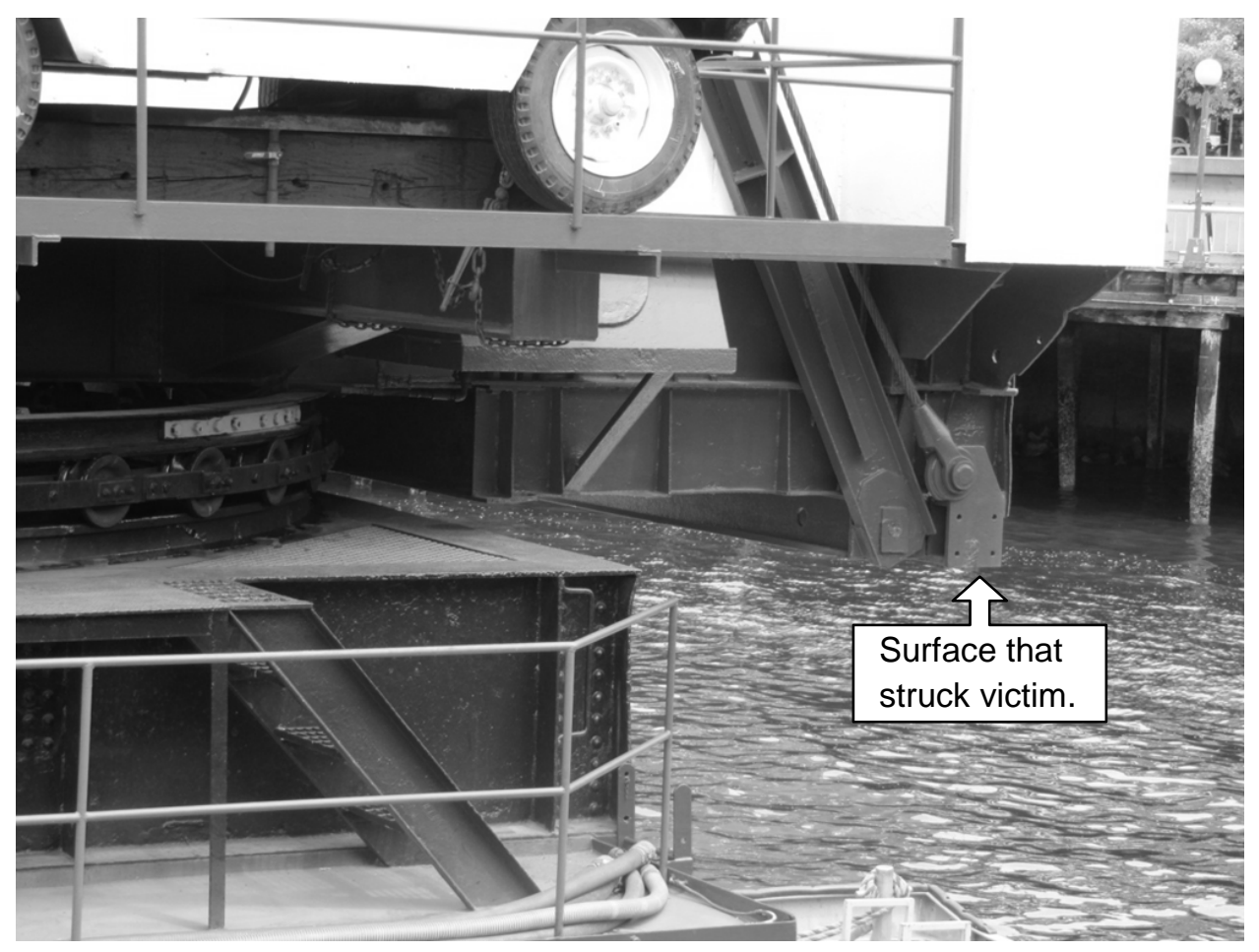

Photo 5: Crane counterweight which struck victim (photo taken shortly after incident).

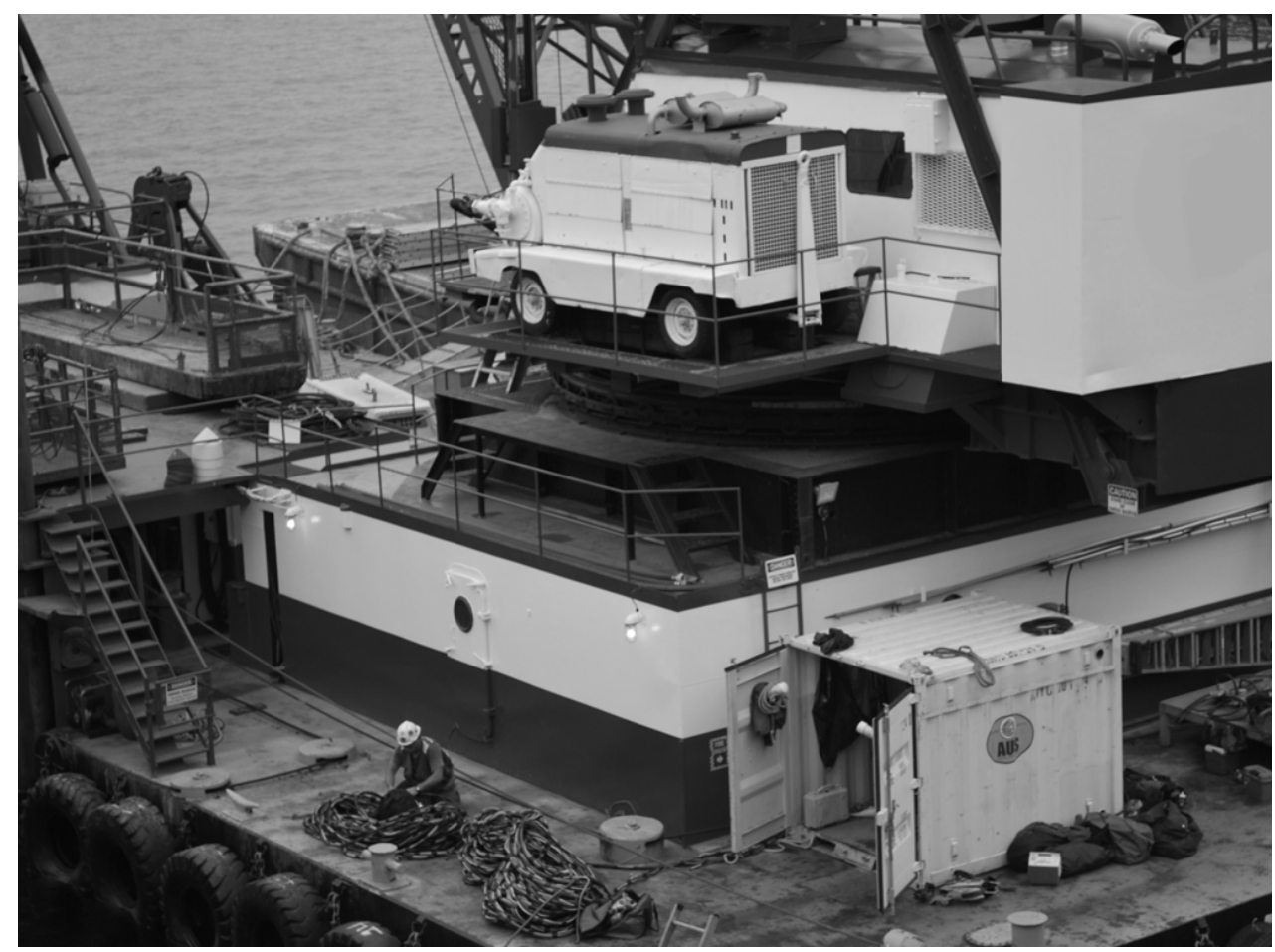

Photo 6: Crane barge at incident site (photo taken over a year later). Note signs warning of crane swing radius and gate and sign placed at foot of stairs which were placed postincident. 


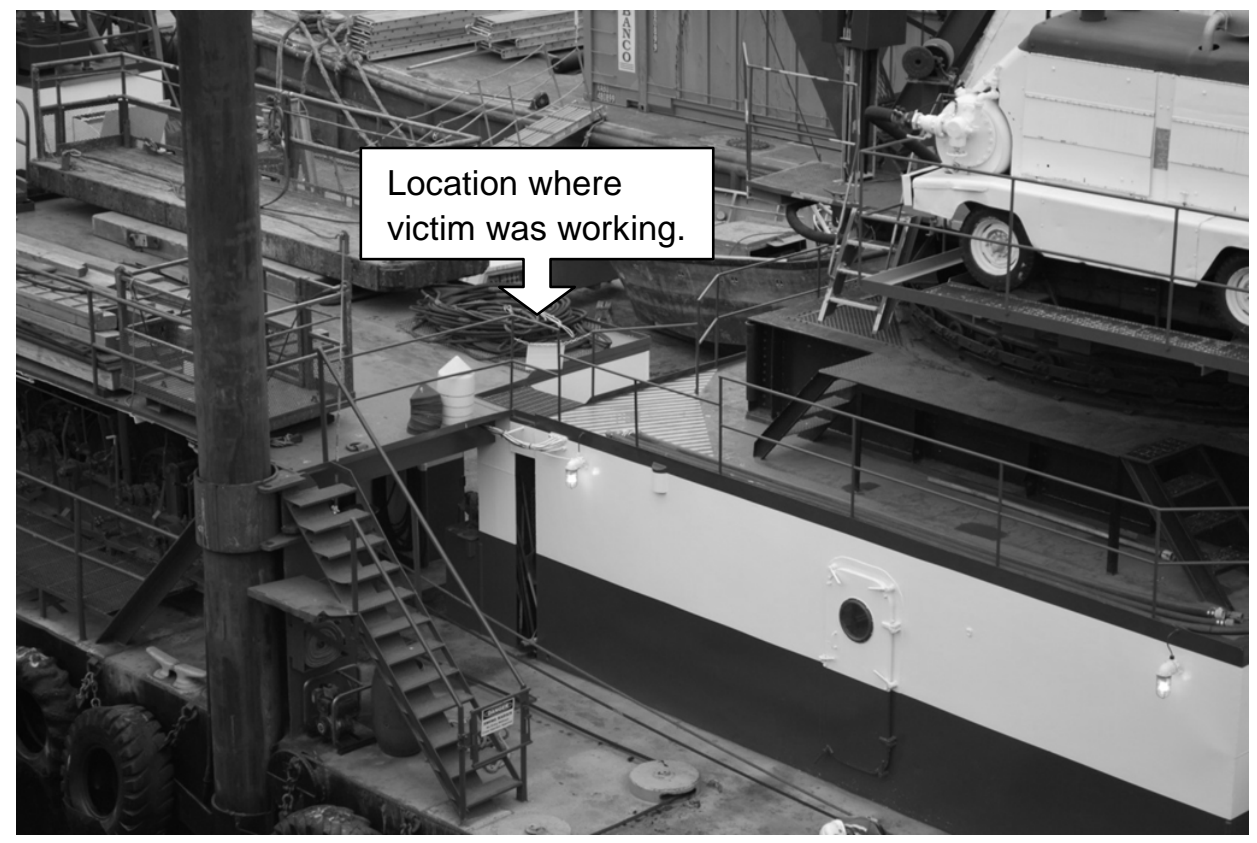

Photo 7: Crane barge showing stairs victim would have used to access upper deck of barge. Note swing gate at bottom of stairs with signage warning of crane swing radius and yellow and black caution stripes on upper deck (area victim was working) warning of area within the radius of the counterweight when the crane swings (photo taken over a year later).

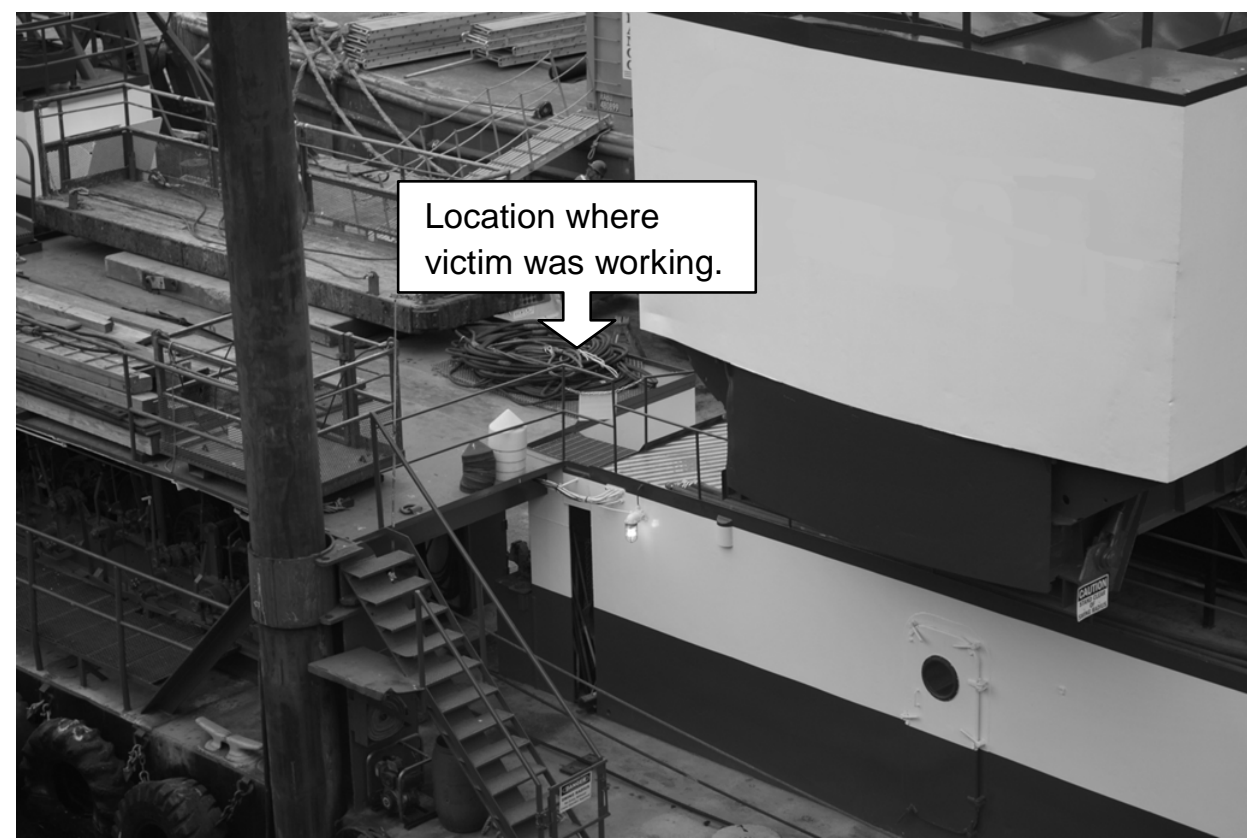

Photo 8: Crane superstructure rotated so that the counterweight is near where it struck the victim who was by the railing in the area of the yellow and black caution stripes painted on upper deck of barge (photo taken over a year later). 

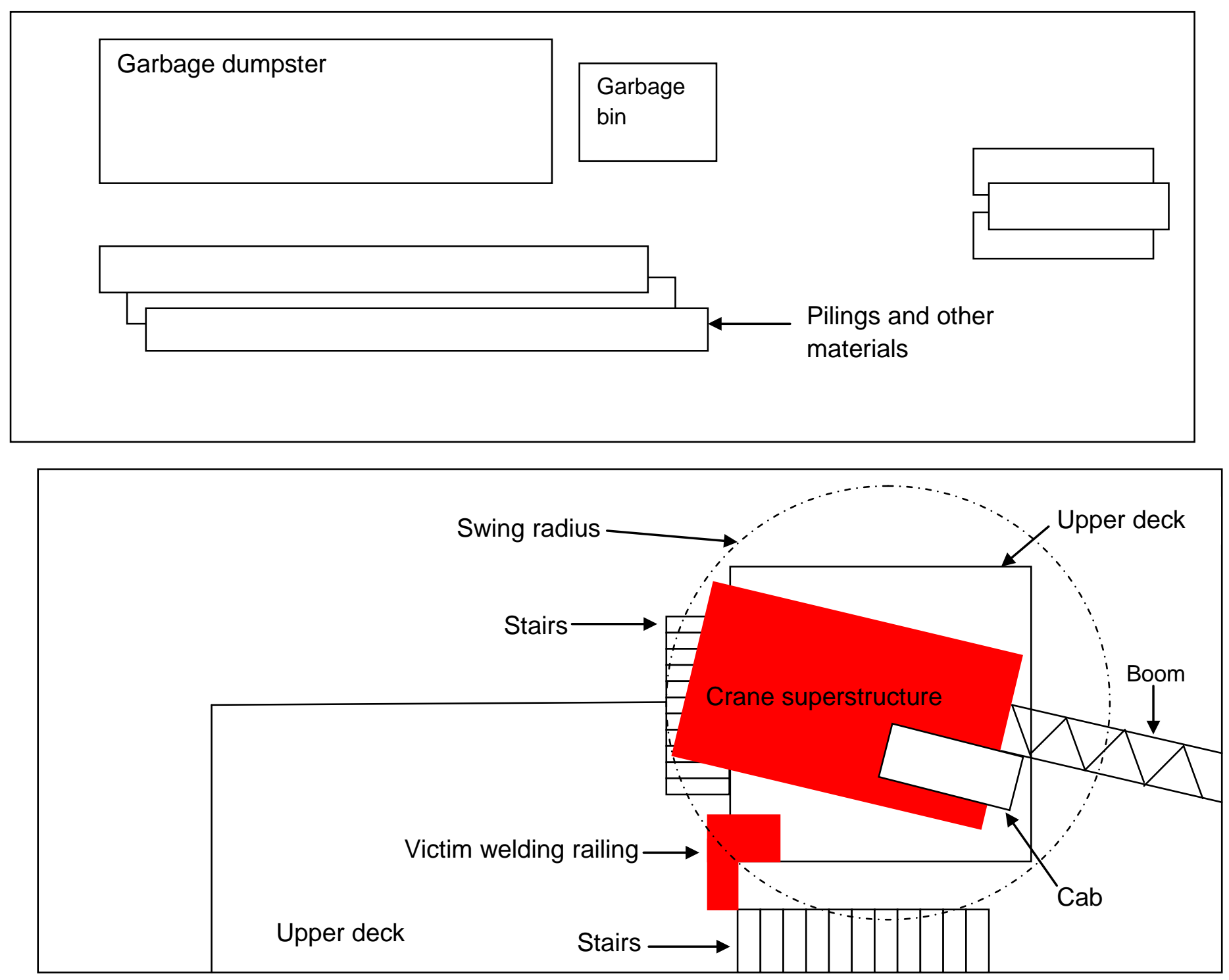

Figure 1. Approximate position and layout of barges prior to the incident. As the crane made the pick from the water to deposit the waste pilings in the garbage bin on the adjacent barge, the crane superstructure rotated counterclockwise, striking the victim while she was making welding repairs to the railing on the barge's upper deck. 


\section{Investigator Information}

Todd Schoonover has a PhD in Industrial Hygiene from the University of Illinois at Chicago. He is a Certified Industrial Hygienist $(\mathrm{CIH})$ and Certified Safety Professional (CSP). Todd is currently the Principal Investigator for the WA FACE program.

Eric Jalonen has a Master's degree in Public Health from East Carolina University. He is currently a Research Investigator with the WA FACE Program.

Randy Clark has a BA from The Evergreen State College. He is a Research Analyst with the WA FACE program.

\section{Washington State FACE Program Information}

The Washington State Fatality Assessment and Control (WA FACE) program is one of many workplace health and safety programs administered by the Washington State Department of Labor \& Industries' Safety \& Health \& Research for Prevention (SHARP) program. It is a research program designed to identify and study fatal occupational injuries. Under a cooperative agreement with the National Institute for Occupational Safety and Health (NIOSH), WA FACE collects information on occupational fatalities in WA State and targets specific types of fatalities for evaluation. WA FACE investigators evaluate information from multiple sources. Findings are summarized in narrative reports that include recommendations for preventing similar events in the future. These recommendations are distributed to employers, workers, and other organizations interested in promoting workplace safety. NIOSH-funded, state-based FACE programs include: California, lowa, Kentucky, Massachusetts, Michigan, New Jersey, New York, Oregon, and Washington. WA FACE does not determine fault or legal liability associated with a fatal incident. Names of employers, victims and/or witnesses are not included in written investigative reports or other databases to protect the confidentiality of those who voluntarily participate in the program.

Additional information regarding the WA FACE program can be obtained from:

Washington State FACE Program

www.Ini.wa.gov/Safety/Research/FACE/default.asp

PO Box 44330

Olympia, WA 98504-4330

1-888-667-4277 


\section{ACKNOWLEDGMENTS}

This report was reviewed by stakeholders from labor and business communities and various Washington State and Federal worker safety agencies. Though we are unable to acknowledge specific individuals for their contributions to this report, we would like to recognize the following for their help and support of the FACE mission and objectives:

- The employer's representatives

- Division of Occupational Safety and Health (DOSH)

- Federal FACE Program Management (NIOSH)

- Safety \& Health Assessment \& Research for Prevention (SHARP)

- Washington State Attorney General's Office

- OSHA Region 10 